\title{
Multidisciplinary treatment of a giant craniofacial neurofibroma with intratumoral hemorrhage
}

\section{Figure Giant craniofacial neurofibroma}

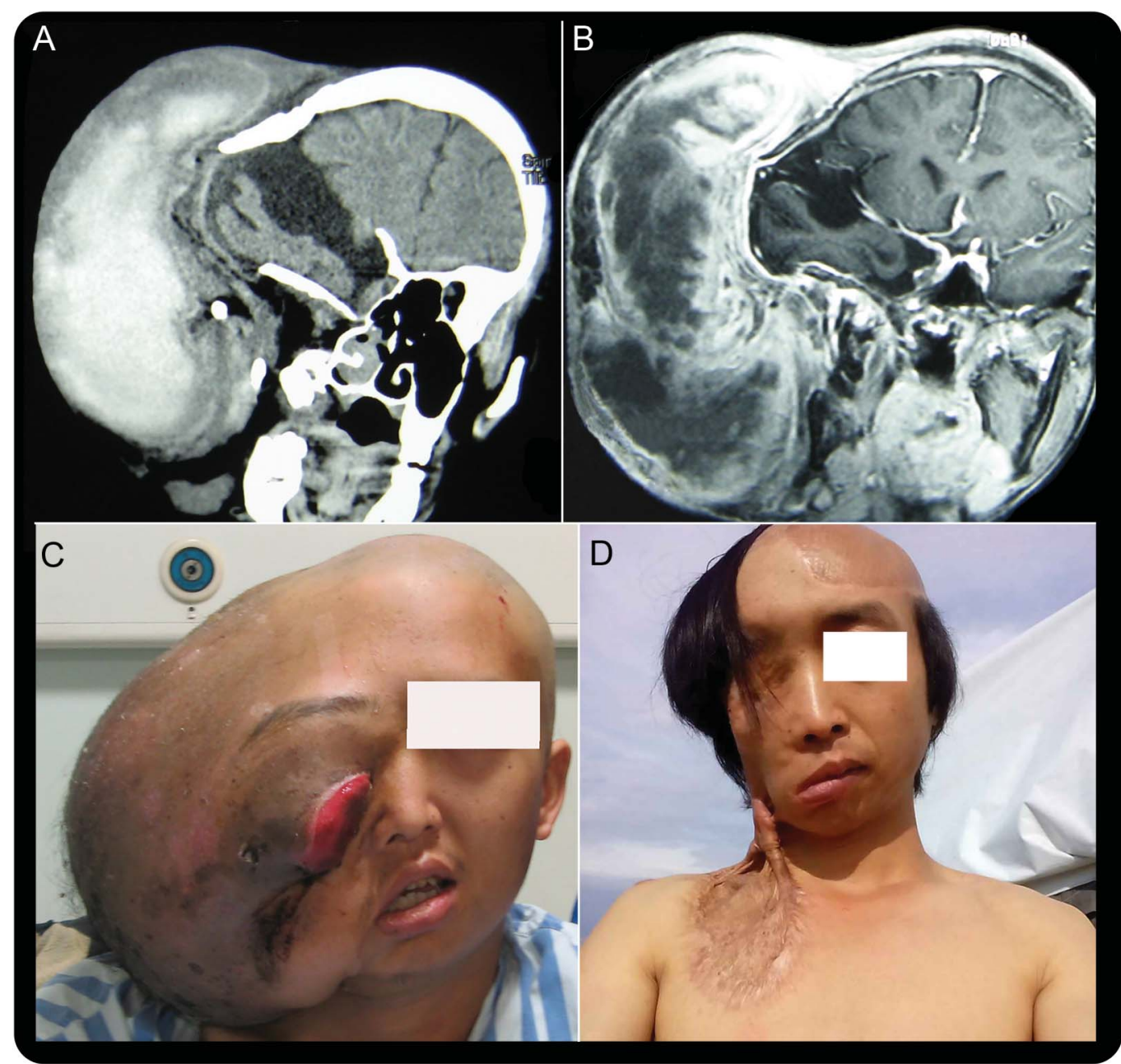

(A) Preoperative CT shows sphenoidal wing dysplasia and defects of cranial bone. (B) Preoperative MRI shows the giant lesion with intratumoral hemorrhage. (C) Preoperative image of the patient. (D) Image of the patient 6 years after surgery.

A 19-year-old man presented with a rapidly growing right craniofacial lump and headache for 9 days, with vision loss in the right eye and no other manifestation of neurofibromatosis or neurologic disturbance. Imaging revealed a giant lesion with intratumoral hematoma and adjacent bone dysplasia (figure, A and B). The tumor and the involved right eye (figure, C) were removed following preoperative embolization. The wound was repaired using dorsal and lateral cervicothoracic flap grafting. Pathologic examination revealed a neurofibroma without malignant transformation. ${ }^{1}$ Solitary giant craniofacial neurofibromas with intratumoral hemorrhage are rare and require multidisciplinary care ${ }^{2}$ for optimal outcome (figure, D). Early intervention is preferable.

Peizhi Zhou, MD, Senlin Yin, MD, Feng Ye, MD, Shu Jiang, $M D$

From West China Hospital, Sichuan University, China. 
Author contributions: All authors were involved in clinical care and investigative workup of the patient. Dr. Zhou and Dr. Jiang provided pictures of the patient and drafted and revised the manuscript. Dr. Yin and Dr. Ye performed follow-up of the patient and revised the manuscript.

Study funding: No targeted funding reported.

Disclosure: The authors report no disclosures relevant to the manuscript. Go to Neurology.org for full disclosures.

Correspondence to Dr. Jiang: jiangshu2000@126.com

1. Jouhilahti EM, Peltonen S, Heape AM, Peltonen J. The pathoetiology of neurofibromatosis 1. Am J Pathol 2011;178:19321939.

2. Hirbe AC, Gutmann DH. Neurofibromatosis type 1: a multidisciplinary approach to care. Lancet Neurol 2014;13:834-843.

\section{WriteClick ${ }^{\circledR}$ rapid online correspondence}

The editors encourage comments about recent articles through WriteClick:

Go to Neurology.org and click on the "WriteClick" tab at the top of the page. Responses will be posted within 72 hours of submission.

Before using WriteClick, remember the following:

- WriteClick is restricted to comments about studies published in Neurology within the last eight weeks

- Read previously posted comments; redundant comments will not be posted

- Your submission must be 200 words or less and have a maximum of five references; reference one must be the article on which you are commenting

- You can include a maximum of five authors (including yourself)

\section{Visit the Neurology ${ }^{\circledR}$ Web Site at Neurology.org}

- Enhanced navigation format

- Increased search capability

- Highlighted articles

- Detailed podcast descriptions

- RSS Feeds of current issue and podcasts

- Personal folders for articles and searches

- Mobile device download link

- AAN Web page links

- Links to Neurology Now ${ }^{\circledR}$, Neurology Today ${ }^{\circledR}$, and Continuum ${ }^{\circledR}$

- Resident \& Fellow subsite

(1) Find Neurolog $y^{\circledR}$ on Facebook: http://tinyurl.com/neurologyfan

twitter Follow Neurology ${ }^{\circledR}$ on Twitter: https://twitter.com/GreenJournal 


\section{Neurology}

\section{Multidisciplinary treatment of a giant craniofacial neurofibroma with intratumoral hemorrhage \\ Peizhi Zhou, Senlin Yin, Feng Ye, et al. Neurology 2015;85;1004-1005 \\ DOI 10.1212/WNL.0000000000001928}

This information is current as of September 14, 2015

\section{Updated Information \&} Services

References

Subspecialty Collections

\section{Permissions \& Licensing}

Reprints including high resolution figures, can be found at: http://n.neurology.org/content/85/11/1004.full

This article cites 2 articles, 0 of which you can access for free at: http://n.neurology.org/content/85/11/1004.full\#ref-list-1

This article, along with others on similar topics, appears in the following collection(s):

All Imaging

http://n.neurology.org/cgi/collection/all_imaging

Medical care

http://n.neurology.org/cgi/collection/medical_care

Models of care

http://n.neurology.org/cgi/collection/models_of_care

Nerve tumor

http://n.neurology.org/cgi/collection/nerve_tumor

Surgical therapy-tumor

http://n.neurology.org/cgi/collection/surgical_therapytumor

Information about reproducing this article in parts (figures,tables) or in its entirety can be found online at:

http://www.neurology.org/about/about_the_journal\#permissions

Information about ordering reprints can be found online:

http://n.neurology.org/subscribers/advertise

Neurology ${ }^{\circledR}$ is the official journal of the American Academy of Neurology. Published continuously since 1951, it is now a weekly with 48 issues per year. Copyright @ 2015 American Academy of Neurology. All rights reserved. Print ISSN: 0028-3878. Online ISSN: 1526-632X.

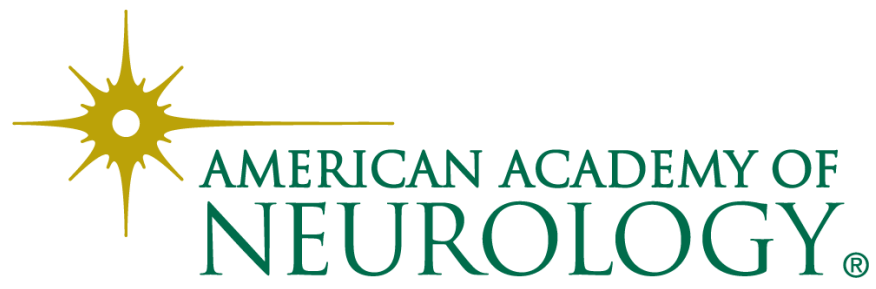

